\title{
Informal Economy in Albania
}

\author{
Merita Boka \\ PhD candidate in Financial Markets and Intermediaries \\ Department of Management, University of Bologna, Italy. \\ meritaboka@gmail.com \\ Giuseppe Torluccio \\ Associate Professor of Banking \& Finance \\ Department of Management, University of Bologna, Italy. \\ Center for Research in Banking and Finance (CEFIN) \\ University of Modena and Reggio Emilia, Italy. \\ giuseppe.torluccio@unibo.it
}

\section{Doi:10.5901/ajis.2013.v2n8p212}

\begin{abstract}
The main purpose of this paper is to assess the size of the informal sector of the economy in Albania by using indirect approaches: national accounts discrepancies, simple currency ratio, electrical energy consumption and some evidence by the labor market developments. A few studies have attempted to estimate the size of the informal economy in Albania in the previous years and there's no evidence of recent estimates of informality (at least they are not publicly available), especially after 2007. Also, there are some other available studies which give some point assessments of informality in Albania but without information on its development over time. Using indirect measurement approaches we found that informality still accounts for a large share to GDP, but, differently from findings in other studies we found lower figures. This may be the result of vast reforms and a formalization process undertaken by the Albanian governments over time. Despite these results, it's important to highlight the fact that the average ratio of the informal sector of the economy to GDP presents a declining trend over the period 1996 - 2012.
\end{abstract}

Keywords: Albania, informal economy, indirect approaches, economic development.

\section{The Informal Economy in Albania: Genesis and Development}

Genesis of the informal economy in Albania can be found in the early stages of transition towards an open market economy at a time when the development of the legal, regulatory and institutional framework progressed at a slower pace compared to private enterprises. The sudden political and economic changes, causing transitional shocks, created a favorable ground for informality to flourish in Albania. Gërxhani (1998) argues that the crisis of the years 1990-1992 was crucial to this phenomenon. This condition served as a strong impulse to respond in a "creative way", passing over difficulties in the informal sector of the economy (Gërxhani, 1998). According to Ruli (2003), "The most disturbing manifestation of informality in the fiscal area lays in small and medium enterprises even large ones, which are legally registered but hide their incomes, their profits, and the number of employees and the real level of salaries. These businesses represent the majority of economic activities: trade (especially the retail), transport (passenger and freight), with services (bars and restaurants), construction and manufacturing activities which are highlighted and underlined as particularly important in terms of the informal economy." The Albanian Center for Economic Research (ACER) (1999), using a direct survey on informality, found that from the perspective of an enterprise $75 \%$ of respondents stated that tax evasion occurs very often; $73 \%$ of respondents stated that they hide their real profits; and $94 \%$ of respondents stated that tax evasion is caused by the current tax system and policies adopted by the fiscal administration. Regime changes in Albania over 1991-1992 were accompanied by the absence of a regulatory framework for the normal functioning of an open market economy. This created favorable conditions for an informal culture of doing business, without rules and without control. At the time public authorities were too weak to exercise control and were also suffering from lack of experience in an open market economy. All of these factors were manifested in the economic, social and political turmoil that accompanied the collapse of pyramid schemes in the years 1996-1997, which delayed further development of a 
coherent institutional framework, thus widening the gap between institutions and the real economy. This can be considered as one of the most extreme examples of consequences brought about by the informal economy in the politics and economy of a country. In recent years, considerable efforts have been made to reduce the informal economy, but the informal economy rate as a percentage of GDP still remains high (OECD, 2004). On the other hand, according to Gërxhani (2003) the informal sector helped the Albanian economy during the first years of transition by providing households with employment and supplementary income in the absence of other opportunities. According to the OECD (2004), the informal sector has been the most dynamic component of the economy in Albania. This has pushed informal activities into becoming a structural and problematic element of the Albanian economy. Factors behind the informal economy have evolved over time. In a joint study carried out by EBRD-WB in 1999, policy instability, crime and corruption were underlined as the main causes of informality. Muço \& Sanfey (2002), in a survey on more than 100 small and medium enterprises, concluded that the biggest problem for businesses operating in the formal sector of the economy was the unfair competition from the informal sector of the economy, followed by constrained access to finance and taxes. In addition to classic causes of the informal economy, in Albania and in Southeast European countries, a number of similar aspects, specific to these countries, are also observed, such as: lack of trust in public institutions (e.g. legislation, administration, courts and bureaucracies) very often considered as inefficient and corrupt; constraints in doing business; property rights not able to be guaranteed by competent institutions; inadequate strengthening of the legislative and regulatory framework; fiscal burden combined with an inadequate supply of public services and infrastructure; low probability of being discovered as an illegal worker or fiscal evader, leading to cost-benefit calculations where a job in the informal sector is more attractive than a job in the formal and official sector; a widespread acceptance of informal work that makes its reduction almost impossible. Constraints in doing business represent an important factor in determining the informal economy in Albania even though some improvement is now being observed. While some enterprises remain informal because they cannot afford the costs of formalization, others (those that are in a more advanced stage of development) operate partially or totally in an informal way even though they are able to afford at least some of the criteria for being formal (Mlinga \& Wells, 2002). These kinds of enterprises make a cost-benefits estimation between staying informal and regularizing (Loayaza, 1997; Djankov, Lieberman, Mukherjee, \& Nenova, 2002). When the costs of becoming formal are higher than the benefits, then companies prefer to operate informally. Informality in Albania occurs in various forms and in almost all economic activities: (a) external trade channels through non-declared goods and declarations of lower value of imported goods, and transmission of remittances through informal channels; (b) introduction of prohibited goods in the internal market; (c) poor tax collection and weak tax administration; (d) use of working hours, material and equipment of public companies for private purposes; (e) unregistered performance of different sectors of the economy especially those of services, trade and construction; (f) unreported income from agricultural entities; (e) informal lending activity outside banking channels; (g) illegal construction of residential and business premises, usurpation of land (private and public) and land built upon without permission (World Bank, 2006); and (i) non-declaration of employees and declaration of minimum wages.

A number of studies have attempted to estimate, with different methods, the size of the informal economy in Albania. Besides the valuable studies of Schneider (2002) and Christie \& Holzner (2003), the Albanian National Institute of Statistics is engaged in measuring the informal economy in Albania. In these studies the informal sector of the economy is estimated to account for more than one third of the GDP even though according to Olters (2003) the size of the informal sector is 'higher than elsewhere'. Muço, Peter, Luçi, \& Hashorva (2004) using the national discrepancies method for the period 1996-2001, found that the informal sector of the economy accounts on average for about $29.1 \%$ of GDP. Schneider at al. (2010) found that the informal economy in Albania over 1999-2007 accounted in average for about $34.3 \%$ of GDP. The different sources mentioned above suggest a level of informal economy of above $30 \%$, which means negative consequences on tax revenues, low level of public services, poor competition in the private sector, holding back of financial deepening (Gobbi \& Zizza, 2007), and in general more hindrance towards a transparent and functioning market economy, crucial for a country like Albania which aims for sustainable economic development and European Union membership.

\section{Assessing the Informal Economy in Albania.}

The literature on the informal economy expounds several methods of estimation, as mentioned in the first section of this paper. Limiting ourselves to the availability of data relevant to Albania, we use three indirect approaches to assess informality in Albania: national accounts discrepancies, simple currency ratio, and electrical energy consumption. Also, we take a brief look at labor market discrepancies. 


\subsection{National Accounts Discrepancies Method}

In theory and practice, the Gross Domestic Product (GDP) can be calculated by using three different methods: the production, expenditure and income approaches. All of these methods should ideally yield the same aggregates. In general, statistical offices using independent sources of information calculate a higher GDP according to the expenditure approach than the income or production approaches. The rationale behind this argument is that individuals usually tend to hide their income through tax declarations rather than through their consumption in household budget surveys (Öĝünç \& Yilmaz, 2000). Therefore the difference in GDP figures obtained by these two approaches can be interpreted as income generated in the informal sector of the economy. The main problem related to this method is that the discrepancies may be the result of unreported economic activities, errors and failures of national accounts statistics. Muço et al (2004) used the national accounts discrepancies method to assess the size of the informal sector for the period 1996-2001. They found that the informal sector of the economy accounted on average for $29.1 \%$ of GDP for the considered period. Following the same reasoning, we apply the same method for the period 1996 - 2013. Data on GDP by the expenditure approach for the period $1996-2008$ are available from Instat. For the years $2009-2013$ we apply the forecasted GDP growth rate (by expenditure approach) as by IMF (World Economic Outlook, April 2013) to the original time series of GDP by Instat. GDP data by the production approach is available for the period 1996-2011 (preliminary) from Instat. For the years 2012 and 2013 we will apply the projected nominal GDP growth rates as the sum of the average inflation rate (Instat for 2012) and the forecasted real GDP growth rate as by WEO, April 2013 excluding the assumptions on informality (available from Instat for the period 1996 - 2010. For 2011 - 2013 we will assume an average 0.5 percentage points decline in informality).

Table 1. Size of the informal economy for the $1996-2013$.

\begin{tabular}{|c|c|c|c|c|}
\hline & GDP by expenditure approach & GDP by production approach & Difference & $\begin{array}{c}\text { Difference/GDP } \\
\text { by Expenditure }\end{array}$ \\
\hline 1996 & 346403.2 & 257377.4 & 89025.8 & $34.6 \%$ \\
\hline 1997 & 346197.8 & 244415.8 & 101782.0 & $41.6 \%$ \\
\hline 1998 & 409208.8 & 297904.2 & 111304.7 & $37.4 \%$ \\
\hline 1999 & 471578.5 & 331990.9 & 139587.6 & $42.0 \%$ \\
\hline 2000 & 523043.4 & 372406.6 & 150636.8 & $40.4 \%$ \\
\hline 2001 & 583368.6 & 416525.5 & 166843.1 & $40.1 \%$ \\
\hline 2002 & 622710.8 & 444615.7 & 178095.1 & $40.1 \%$ \\
\hline 2003 & 694097.5 & 501832.1 & 192265.4 & $38.3 \%$ \\
\hline 2004 & 751021.6 & 541486.9 & 209534.7 & $38.7 \%$ \\
\hline 2005 & 814796.7 & 588283.4 & 226513.3 & $38.5 \%$ \\
\hline 2006 & 882208.8 & 653716.9 & 228491.9 & $35.0 \%$ \\
\hline 2007 & 967670.0 & 719946.5 & 247723.6 & $34.4 \%$ \\
\hline 2008 & 1088132.1 & 832219.9 & 255912.3 & $30.8 \%$ \\
\hline 2009 & 1150155.7 & 877134.6 & 273021.0 & $31.1 \%$ \\
\hline 2010 & 1236417.4 & 964522.6 & 271894.7 & $28.2 \%$ \\
\hline 2011 & 1317891.2 & 1012340.1 & 305551.1 & $30.2 \%$ \\
\hline 2012 & 1364017.4 & 1012981.3 & 351036.1 & $34.7 \%$ \\
\hline 2013 & 1414486.1 & 1066169.2 & 348316.9 & $32.7 \%$ \\
\hline
\end{tabular}

Source: National Institute of Statistics in Albania (INSTAT), IMF, author's calculations.

According to our calculations, the informal sector of the economy still accounts for a large part of GDP even though it has followed a progressive reduction path from year to year. According to the national accounts discrepancies method, the informal sector of the economy accounted on average for about 36.2\% of GDP over the period 1996-2012 and a coefficient of variance (measured as the ratio of the standard deviation to the simple average) of 0.12 . The years after the 1997 financial crises were characterized by high levels of informality (42.0\% of GDP in 1999). Data suggest that after 2006 informality has followed a declining trend till 2011 and increased again in 2012. The results obtained by this method corroborate those of Schneider et al. (2010) on informality. The negative aspect is that informality has been decreasing at a very slow pace from year to year; suggesting that steps undertaken towards formalization have not yet had the desired effects. This method seems very easy to apply but results should be interpreted very carefully. Usually, GDP figures are 
published from statistical offices with time lags, and in each publication previous figures are revised. Also, improvement in existing statistical sources and the introduction of new ones result in lower discrepancies; and statistical errors in calculations may be present. Meksi (2012) investigated how preliminary first estimates of the quarterly GDP, subject to quarterly revisions, are or are not a fundamentally reliable indicator of the respective series. She found that revisions of the quarterly GDP were high in average terms compared to 7 OECD countries where they are generally 0 . Meksi (2012) also found that revised GDP figures are significantly different from the last released ones. Also, Feige \& Urban (2008), in the case of Greece, suggest that every major revision in the published accounts must somehow be made comparable with previous published data in order not to distort perceptions of changes in total output over time. Stringent safeguards for consistency and transparency are crucial at this point in order to avoid allegations that the accounts have become more subjective and opaque, and thereby more potentially vulnerable to political manipulation. As a result, using the GDP approach in the case of Albania to assess the informal economy may lead to misleading conclusions and to questionable reliability of the results. Efforts should be directed especially towards measuring the formal economy, minimizing errors and improving statistical sources, and then using this data to estimate the size of the informal sector of the economy.

\subsection{Simple Currency Ratio (SCR) Method}

According to Cagan (1958), and later Guttman (1977), in cases where there is a lack of data to estimate a complete money demand function, the simple currency ratio method can be used in order to assess the informal economy. In the simplified version proposed by Guttman (1977) changes in cash in the overall money supply are ascribed exclusively to the dynamics of the informal sector of the economy. Muço et al. (2004), in the case of Albania, and Öĝünç \& Yilmaz (2000) for Turkey, used this method to assess the informal economy. Using the following equations and identities:

$\mathrm{C}=\mathrm{C}_{\mathrm{r}}+\mathrm{C}_{\mathrm{u}}$ where $\mathrm{C}$ represents the currency outside banks, $r$ stands for formal and $u$ stands for informal; $\mathrm{D}=\mathrm{D}_{\mathrm{r}}+$ $D_{u}$ where $D$ represents deposits; $k_{r}=C_{r} / D_{r}$ and $k_{u}=C_{u} / D_{u}$ assumed to describe the long run need for cash in both sectors; $V_{r}=Y_{r} /\left(C_{r}+D_{r}\right)$ and $V_{u}=Y_{u} /\left(C_{u}+D_{u}\right)$ indicating the money velocity; $Y$ indicating income (GDP) and $\beta=v_{r} / V_{u}$ yielded the general formula:

$$
Y_{u}=\frac{1}{\beta} Y_{r} \frac{\left(k_{u}+1\right)\left(C-k_{r} D\right)}{\left(k_{r}+1\right)\left(k_{u} D-C\right)}
$$

To obtain a solution this method we consider the following underlying assumptions: (i) there's no use of other payment instruments in the economy, only cash is used; (ii) $k$, ratio of currency outside banks and total deposits remains constant except changes deriving from unreported income increase; (iii) $v$, money velocity in the informal sector and money velocity used in the official sector of the economy is the same. From the first assumption, when $k_{u}$ approaches infinity the limit of $\mathrm{k}_{\mathrm{r}}$ goes to a constant as a result of the second assumption and the third assumption implies that $\beta=1$. Considering the above assumptions the general formula can be written as:

$$
Y_{u}=Y_{r} \frac{\left(C-k_{r} D\right)}{\left(k_{r}+1\right) D}
$$

We apply the simple currency ratio method in the case of Albania to estimate the size of the informal sector of the economy for 1993-2012. We use the currency outside banks and total deposits. GNP data were available only for the period 1996-2010 as by Instat. We calculate GNP for the period 1993-1995 and 2011-2012 by adding the net income factor derived from the Balance of Payments data for Albania to the GDP series (IMF, WEO April 2013 as we did in 4.1). Also, we have to choose a base year where the ratio of currency outside banks to deposits is at a minimum (in this case 2012 where $k=0.21$ ). By doing so, we assume that in that base year there is no informal economy or it is so low that it can be ignored..

Table 2. Simple currency ratio method (base year 2012, in mln Lek).

\begin{tabular}{|c|c|c|c|c|c|c|}
\hline & $\mathrm{C}^{*}$ & $\mathrm{D}^{\star *}$ & $\mathrm{k}=\mathrm{C} / \mathrm{D}$ & $\mathrm{GNP}^{\star \star *}$ & Informal economy & IE \% GDP \\
\hline 1993 & 17989.4 & 31206.7 & 0.58 & 139318.2 & 42636.8 & $\mathbf{3 0 . 4 \%}$ \\
\hline 1994 & 27626.3 & 41811.0 & 0.66 & 211888.7 & 79641.8 & $37.8 \%$ \\
\hline 1995 & 41905.0 & 63518.5 & 0.66 & 255768.0 & 95919.5 & $38.1 \%$ \\
\hline 1996 & 47813.4 & 103575.8 & 0.46 & 322298.0 & 67974.2 & $\mathbf{2 1 . 6 \%}$ \\
\hline 1997 & 72724.3 & 122118.4 & 0.60 & 329484.0 & 106038.7 & $32.9 \%$ \\
\hline 1998 & 68322.4 & 166912.7 & 0.41 & 423925.0 & 71040.9 & $17.2 \%$ \\
\hline 1999 & 81334.1 & 206091.4 & 0.39 & 484755.0 & 75339.4 & $15.9 \%$ \\
\hline
\end{tabular}




\begin{tabular}{|l|c|c|c|c|c|c|}
\hline 2000 & 99233.6 & 222568.3 & 0.45 & 538420.0 & 106521.2 & $\mathbf{2 0 . 4 \%}$ \\
\hline 2001 & 119088.2 & 267031.6 & 0.45 & 601591.0 & 119075.4 & $\mathbf{2 0 . 4 \%}$ \\
\hline 2002 & 130772.2 & 277356.9 & 0.47 & 637988.0 & 139770.2 & $\mathbf{2 2 . 4 \%}$ \\
\hline 2003 & 125187.5 & 318340.0 & 0.39 & 712987.0 & 109983.9 & $\mathbf{1 5 . 8 \%}$ \\
\hline 2004 & 138093.5 & 365138.1 & 0.38 & 772518.0 & 109531.4 & $14.5 \%$ \\
\hline 2005 & 149671.1 & 423312.3 & 0.35 & 836518.0 & 101540.7 & $12.4 \%$ \\
\hline 2006 & 163264.3 & 503203.2 & 0.32 & 907909.0 & 88302.2 & $10.0 \%$ \\
\hline 2007 & 154956.2 & 602653.4 & 0.26 & 994533.0 & 41254.3 & $\mathbf{4 . 3 \%}$ \\
\hline 2008 & 195817.3 & 619887.4 & 0.32 & 1094696.0 & 98707.2 & $9.1 \%$ \\
\hline 2009 & 209043.8 & 662425.7 & 0.32 & 1133876.0 & 101940.8 & $\mathbf{8 . 9 \%}$ \\
\hline 2010 & 195059.0 & 785224.9 & 0.25 & 1228647.0 & 42098.1 & $3.4 \%$ \\
\hline 2011 & 194923.2 & 875226.3 & 0.22 & 1325111.0 & 17189.9 & $1.3 \%$ \\
\hline 2012 & 192705.1 & 930702.7 & 0.21 & 1365315.0 & 0.0 & $\mathbf{0 . 0 \%}$ \\
\hline
\end{tabular}

${ }^{*} \mathrm{C}$ - currency outside banks, end of year stock, Million ALL.

** D - total deposits in Lek, end of year stock, Million ALL.

*** GNP - gross national product, Million ALL.

Source: Bank of Albania, Instat, IMF, author's calculations.

According to the simple currency ratio method, the first years of transition towards an open market economy were accompanied by high levels of informal economy, as expected and consistently with other studies on this topic. The informal sector of the economy accounted on average for about 32.0\% of GDP during 1993-1996. In 1996 our estimations show a notable decline in the informal sector and then a sudden jump over 1997 (coincident with the financial crisis). Estimates for the succeeding years are too low compared to those expected. Also, the coefficient of variation (measured as the ratio of the standard deviation to the simple average) resulted in 0.68 , suggesting high volatility in estimations of the informal economy. Muço et al. (2004) also, did not obtain reliable results using monetary data, and the reasons behind this are primarily concerned with the underlying assumptions we stated above. First of all, the choice of a base year without informal economy is not realistic and brings questionable results. Different base year choices would bring different results in terms of size of the informal sector of the economy. Secondly, there is no reason to believe that the same money velocity exists in both sectors. Since in the informal sector cash is commonly used, the money velocity in this sector should be higher.

\subsection{Kaufmann - Kaliberda Method}

Another method used to assess the informal economy is the Kaufmann-Kaliberda method or the so-called 'electricity consumption method'. By using the physical consumption of energy independently from the national accounts discrepancies method and the simple currency ratio method, we can check the consistency of the previous results (those obtained using the SCR method and the national accounts discrepancies method). As in Kaufmann \& Kaliberda (1996), there is a unitary elasticity of change in consumption of electricity to changes in the overall GDP. The difference between official GDP growth rate and energy consumption can be attributed to increased activity in the informal sector of the economy. In our case we will use the total consumption of electrical energy. We assume that the informal economy in 1993 is $30.4 \%$ of GDP, as calculated by the simple currency ratio method.

Table 3. Informal economy in Albania using Kaufmann - Kaliberda method.

\begin{tabular}{|c|c|c|c|c|}
\hline & $\begin{array}{c}\text { GDP* growth } \\
\text { rate, in \% }\end{array}$ & $\begin{array}{c}\text { Electricity consumption } \\
\text { changes, in \% }\end{array}$ & $\begin{array}{c}\mathrm{IE}, \% \text { of GDP } \\
\text { (change) }\end{array}$ & $\begin{array}{c}\text { IE as \% of GDP (IE in 1993 = } \\
30.4 \%, \text { SCR method) }\end{array}$ \\
\hline 1994 & $49.9 \%$ & $12.2 \%$ & $-37.8 \%$ & $68.1 \%$ \\
\hline 1995 & $19.6 \%$ & $16.1 \%$ & $-3.5 \%$ & $33.9 \%$ \\
\hline 1996 & $25.0 \%$ & $12.9 \%$ & $-12.2 \%$ & $42.5 \%$ \\
\hline 1997 & $2.3 \%$ & $3.7 \%$ & $1.4 \%$ & $28.9 \%$ \\
\hline 1998 & $28.0 \%$ & $0.3 \%$ & $-27.7 \%$ & $58.1 \%$ \\
\hline 1999 & $15.0 \%$ & $13.3 \%$ & $-1.7 \%$ & $32.1 \%$ \\
\hline 2000 & $10.3 \%$ & $-0.1 \%$ & $-10.3 \%$ & $40.7 \%$ \\
\hline 2001 & $11.5 \%$ & $-5.4 \%$ & $-16.9 \%$ & $47.3 \%$ \\
\hline
\end{tabular}




\begin{tabular}{|c|c|c|c|c|}
\hline 2002 & $6.7 \%$ & $0.0 \%$ & $-6.8 \%$ & $37.1 \%$ \\
\hline 2003 & $11.5 \%$ & $8.7 \%$ & $-2.8 \%$ & $33.2 \%$ \\
\hline 2004 & $8.7 \%$ & $0.8 \%$ & $-8.0 \%$ & $38.3 \%$ \\
\hline 2005 & $8.7 \%$ & $-0.2 \%$ & $-8.9 \%$ & $39.2 \%$ \\
\hline 2006 & $7.6 \%$ & $3.2 \%$ & $-4.4 \%$ & $34.7 \%$ \\
\hline 2007 & $9.7 \%$ & $-6.6 \%$ & $-16.3 \%$ & $46.6 \%$ \\
\hline 2008 & $12.6 \%$ & $10.2 \%$ & $-2.4 \%$ & $32.8 \%$ \\
\hline 2009 & $5.7 \%$ & $4.6 \%$ & $-1.0 \%$ & $31.4 \%$ \\
\hline 2010 & $7.5 \%$ & $5.7 \%$ & $-1.7 \%$ & $31.6 \%$ \\
\hline 2011 & $6.6 \%$ & $5.3 \%$ & $-1.2 \%$ & $24.4 \%$ \\
\hline 2012 & $3.5 \%$ & $9.4 \%$ & $6.0 \%$ & $27.0 \%$ \\
\hline $2013^{\star *}$ & $3.7 \%$ & $7.1 \%$ & $3.4 \%$ & \\
\hline
\end{tabular}
* GDP time series from IMF (WEO, April 2013).
* Total electrical energy consumption for 2013 estimated by applying the average growth rate in electrical energy consumption in
the last five years.

Source: IMF, Albanian Energy Regulatory Entity (ERE), author's calculations.

The results suggest that informality level in Albania marked its highest value in 1994, about $68.1 \%$ of GDP. In average for the period 1996 - 2012 the informal economy accounted for about 37.1\% of GDP and the coefficient of variation was 0.28 . Also, from the estimations obtained using this method we found that even following a declining trend over time, informality in Albania still accounts for a large share of GDP. Using IMF projections on GDP for 2013 and applying the average growth rate in electrical energy consumption in the last five years we obtain a projection of the size of the informal sector for 2013. According to these projections, the size of the informal sector is expected to increase in 2013 to $27.0 \%$ on GDP. This result may be related to the relative political instability of the last year and the forthcoming elections of June 2013.

This attractive and simplified method of estimating the size of the informal sector of the economy has been widely criticized. The method does not take into account a number of factors: the differences between electricity intensive and labor intensive industries (some service industries which are labor intensive easily switch to the informal sector); technological improvement which leads to lower energy consumption and alternative energy sources (Schneider \& Enste, 2000); rationing of electricity since Albania depends on hydro-production of electricity; unreliable data on consumption since part of the energy is stolen; and non-payment of energy bills by both enterprises and households. The results on informality using the electricity consumption method does not support those obtained using the simple currency ratio. Instead, they are rather consistent with those generated using the national accounts discrepancies method.

\section{Formalizing the Informal Economy in Albania.}

The existence of the informal sector of the economy in Albania has been, and still is, considered a serious challenge faced by the government. In order to reduce its size and to soothe its consequences in the economy, several measures should be taken. According to Gërxhani (1997), efforts should be focused on the following: improvement and modernization of a legal institutional framework, improvement and creation of a favorable business climate, reduction of bureaucracies, accountability and transparency of legal institutions, property rights protection, further financial development, a flexible and effective system of taxation and social and health insurance contribution system, and improvement of statistical systems. Besides the relatively positive contribution of the informal sector in relieving poverty effects and sustaining consumption in the first years of transition, it is not sufficient to support the long-term economic growth, financial deepening and integration of the country. At this point, the integration of the informal sector into the formal sector of the economy is becoming an emergent element for the future sustainable economic development of Albania. One of the steps undertaken by the Government of Albania is the adoption of the "Action Plan for the Reduction of the Informal Economy for 2006-2009". Approval of this action plan was formalized with the Decision no. 430, dated 28.6.2006, which organized the central reviewing group and the implementation of the action plan for reducing the 
informal economy in Albania ${ }^{1}$. Simultaneously with the informal economy, the cash-based economy has also developed. Data show that in Albania there is still a large amount of currency outside banks which fuels the informal sector of the economy and also reduces the effectiveness of monetary policy decisions and transmission. The ratio of currency outside banks to monetary aggregate M3 has decreased steadily from 39.0\% in 1994 to 16.7\% in 2012 (data refers to the end of November 2012), but it still remains high. Infrastructural changes in the banking sector, which have helped to reduce currency outside banks, include the following: a better distribution of the banking sector throughout Albanian territory ${ }^{2}$; an increased number of banking services which facilitate financial transactions, and an improved payment system ${ }^{3}$; reduction in the number of documents requested by banks; ATM ${ }^{4}$ and POS 5 , debit cards ${ }^{6}$, credit cards ${ }^{7}$ and e-banking; and the establishment of the credit register ${ }^{8}$ for the Republic of Albania. Other important decisions taken concern the transfer of public administration salaries through banks, distribution of pensions from post offices, and payment of monthly bills for electricity, water and phone by e-banking. Also, the decision according to which businesses of all sizes are obliged to open and conduct transactions by means of bank accounts is an important measure for reducing cash and informality. The fight against fiscal evasion, corruption and informality represents a considerable challenge faced by the General Tax Directorate (GTD) in collaboration with the Ministry of Finance (MoF). Efforts have been concentrated on extending the taxable basis and higher tax compliance, modernizing the fiscal administration, legislative improvements, and higher credibility and commitment of the tax administration, since operating in the formal sector of the economy means being subject of a series of expenses, because of their importance, fiscal burden and complexity of the fiscal system have a major impact. Reducing the fiscal burden has been a policy priority in recent years. Profit tax was reduced from $30 \%$ in 2000 to $10 \%$ in 2008 in order to encourage businesses to declare the real figures of their balance sheets. In this way, they are enabled to access financial resources from the banking sector, which will be result in in higher investment, employment and economic development. With regard to personal income tax, a flat tax system was introduced (2007), eliminating the progressive taxation scale and keeping an exclusive threshold level of 10,000 Albanian Lek for salaries up to 30,000 Lek. All categories of PIT have been taxed at the same level of $10 \%$ since the second half of 2007. In order to respect all commitments with the EU and WTO, the customs tax for imported vehicles was reduced to $0 \%$ from July 2007. Also, the reduction of the social and health insurance contributions rate 9 from $41.9 \% 10$ in 2002 to $27.9 \% 11$ from 2009 is having a positive impact on revenues and number of new contributors. Further reforms have been undertaken, aiming at the improvement of tax administration, the information system and the service for tax payers, by improving communication and providing information through the internet or other means. This has led to a reduction in unnecessary taxpayer contacts with the tax administration, through the delivery of service of declaration and payment online. Since February $2010^{12}$, on the General Tax Directorate official web site ${ }^{13}$, businesses have been able to make declarations electronically regarding VAT, personal income tax, profit tax, and social and health insurance contributions. From January $2012^{14}$, the GTD has increased the number of declarations and forms to be presented only electronically

${ }^{1}$ The working group chaired by the Minister of Economy, Trade and Energy and include the Deputy Minister of Finance, Deputy Minister of Labor, Social Affairs and Equal Opportunities, General Director of the Department of Taxation, General Director of INSTAT, the General Director of the ISS and will be in charge, setting up technical working groups in relevant fields and reviewing and implementing the action plan.

${ }^{2}$ In 2011 there were 16 operating banks in Albania with 399 branches and 130 agencies operating in the territory of the Albanian Republic, 19 non-bank financial institutions, 301 foreign currency exchange offices. Source: Bank of Albania

${ }^{3}$ From 2003 RTGS system was introduced and from June 2005 AECH system was introduced. Source: Bank of Albania

4 In 2011 (the first 9 months) there were about 805 ATMs, up from 93 in 2004. Source: Bank of Albania

5 In 2011(the first 9 months) there were about 5126 POS installed, up from 155 in 2004. Source: Bank of Albania

${ }^{6}$ In 2011 (the first 9 months) there were about 687597 debit cards, up from 33288 in 2004. Source: Bank of Albania

7 In 2011 (the first 9 months) there were about 31391 credit cards, up from 806 in 2004. Source: Bank of Albania

${ }^{8}$ From 18.07.2007.

${ }_{9} \mathrm{~A}$ widespread practice is that wages are declared at the minimum level in order to pay contributions on that basis, while the difference resulting from the real and the declared salary is paid to the employee in cash.

${ }^{10}$ Decision Nr. 346, dated 13.06.2002, On some changes in the Decision no. 402, dated 11.06.2001 of Council of Ministers "On some issues for the implementation of Law no. 7703, dated 11.05.1993 "On social insurance in Rep. of Albania ", amended by the relevant laws and the law No. 7870, dated 13.10.1994" On health insurance Rep. of Albania ", amended the relevant laws"

${ }^{11}$ Statement of the Prime Minister during the Council of Ministers 20.08.2008.

${ }^{12}$ Council of Ministers Decision No. 55, dated 03.02.2010 and Order of the Minister of Finance No 2, dated 28.01.2010.

${ }^{13}$ Web site: www.tatime.gov.al

${ }^{14}$ Council of Ministers Decision No. 899, dated 14.12.2011, amending CMD No.55 dated 03.02.2010. 
by businesses regarding payroll and social and health insurance contributions, personal income taxes, number of employees, first-time employments, re-employments, and those who have recently left small business tax. Great importance is given to the establishment of fiscal devices which had to be installed by businesses up to the end of December $2010^{15}$. This is expected to have a very positive impact on informal economy reduction, fair competition and higher revenues to tax administration. At the end of 2009, some amendments were proposed to the law on tax procedures that aim the reduction of informal economy and specifically deal with: self-employed individuals about the registration and payment of social insurance contributions or their de-registration; non declaration of employed individuals, setting more severe penalties for any newly employed non declared; penalties for not installed fiscal devices. After the first years of transition, informal construction activity by both individuals and enterprises, for housing and business purposes, flourished in Albania. None of this was declared to the competent authorities and no taxes were paid for them. Households and enterprises could not use this as collateral and could not access credit in formal markets, thus hindering financial deepening. According to the UNDP, this created a huge amount of 'dead capital', amounting to about US\$ 15.8 billion (in 2004), and equal to 11.7 times the total reserves minus gold of 2004, and 11.4 times FDI-S (19932004). In order to mobilize this dead capital and in the context of formalization of the economy (this is part of the complex reform on property rights), an Agency for Legalization, Urbanization and Integration of Informal Areas/Constructions $\left(\right.$ ALUIZNI) ${ }^{16}$ in Albania was constituted. This agency was established as an executive structure, responsible for managing the legalization, urbanization and integration of informal areas/settlements across the country. This process is still going on in Albania. Important steps have been undertaken to improve aspects of doing business. Comprehensive reform has been undertaken in order to permit free entrance and exit of businesses to and from the market. According to the 'Doing Business' Report, Albania improved its ranking by 54 positions (from 136 to 82) during 2008, and was declared second in the world in terms of quality and intensity of reforms to improve the business climate in the country for the period 20072008. In this context, it is worth noting the adoption of the new legislation for the establishment and operation of the National Registration Center (NRC), which changes business registration from a legal act at the court of Tirana into a simple administrative procedure (registration of a business in one day and for 0.81 Euros). Lowering registration costs reduces the number of contacts with administrative employees, and so reduces corruption. The NRC started operating on September 10, 2007, and operated as a "one-stop-shop" to register a business within a single day for 2008, 2009, 2010 and 2011. Reforms carried out during 2007 brought about a reduction in the number of steps for starting a business from ten to five, in 2008, 2009, 2010 and 2011. With recent changes, the law on chambers of trade and industry has been amended, by removing the obligation of companies to be registered in this institution. In 2007 about 36 days were needed to start a new business. In 2008, this was reduced to 7 days, and from 2009 to 2011 a new business could be started in 5 days. Another change concerns licenses: 104 out of 166 licenses and permits have now been removed. Albania is now a country with one of the smallest number of permits and licenses in Europe and beyond. In 2009 the National Licensing Center (one-stop-shop for licenses) was established, and a silent consent principle was implemented. At the beginning of 2011 the "Electronic register for business law" was functioning. This contains all legislative acts from 30 institutions on line.

\section{Conclusions}

In this paper we have attempted to assess the size of the informal economy in Albania from the first years of transition until 2012 and gave some hints about informality over 2013. We used four different indirect measurement approaches to assess the informal economy in Albania: national accounts discrepancies, simple currency ratio, the electricity consumption method and some evidence from labor market discrepancies. Overall, according to the previous methods of estimation, the informal economy in Albania still accounts for a large share of GDP. Using the electrical energy consumption method we obtained the highest values of informality (on average informality accounts for about $37.81 \%$ of GDP for the period 1996-2012), and with the simple currency ratio the lowest ones (on average informality accounts for about $13.6 \%$ of GDP for the period 1996-2012). National accounts discrepancies suggest that the informal economy still

\footnotetext{
${ }^{15}$ CMD No. 781, dated 14.11.2007 "on Technical and functioning characteristics of fiscal devices, computerized integrated system on periodical automatic transfers of fiscal declarations, communications system, on the procedure and documentation (...)"

${ }^{16}$ Law No. 9482, dated 03.04.2006 on "Legalization, urbanization and integration of informal areas/constructions " and further updates: Law No. 9786, dated 19.07.2007; Law No. 9895, dated 09.06.2008; Constitutional Court Decision No. 3, dated 02.02.2009; Law No. 10099, dated 19.03.2009; Law No. 10169, dated 22.10.2009; Law No. 10219, dated 04.02.2010.
} 
accounts on average for about $36.2 \%$ of GDP over the period 1996-2012. The results obtained with the simple currency ratio method are the most volatile, as measured from the coefficient of variance, and those from the national accounts discrepancies the least volatile ones. Muço et al. (2004) also found that the estimations of the size of the informal economy using the monetary method were unreliable, since they led to absurdly high estimates for the informal economy. In our case, the result was the same but the simple currency ratio method yielded very low estimates of the size of the informal economy in Albania. The results obtained using the national accounts discrepancies method are supported by those obtained from the electricity consumption method and both of them corroborate those obtained by Schneider et al. (2010). All the methods used to assess the informal economy in Albania are constrained by the absence and accuracy of the data and the restrictive assumption on which each estimation method lies. Furthermore, there is no "best" method to assess the informal sector of the economy. What seems important from our estimates is that informality has followed a declining trajectory over time. This may be the result of all the widespread reforms undertaken by the Albanian government and other institutions in order to reduce the informality, the introduction of a new culture of doing business, attempts by the banking system to achieve further financial deepening, and constraints imposed by the European integration process.

\section{Acknowledgements}

This paper was realized with the financial support of the Excellence Fund Program, Ministry of Education and Science, Albania.

\section{References}

ACER. (1999). Informal economy in Albania: study of hidden employment and tax evasion. Albanian Center for Economic Research . Cagan, P. (1958). The demand for currency relative to the total money supply. Journal of Political Economy, 66:3, pp. 302 - 28.

Christie, E., \& Holzner, M. (2003). The dark side of the Balkans (the shadow economy in the Southeast Europe). GDN Workshop on Enterprise Development, the Informal Economy and Labour Markets. The Vienna Insitute for International Economic Studies.

Djankov, S., Lieberman, I., Mukherjee, J., \& Nenova, T. (2002). Going informal: benefits and costs. Draft: The World Bank.

Feige, E. (1996). Overseas holdings of US currency and the underground economy. In S. Pozo, Exploring the underground economy (pp. 5-62). Michigan: Upjohn Institute for Empolyment Research.

Feige, E. L., \& Urban, I. (2008, March). Measuring underground (unobserved, non - observed, unrecorded) economies in transition countries: Can we trust GDP? The William Davidson Institute, University of Michigan.

Gërxhani, K. (1997). Unregistered employment and fiscal implications: aspects of informal sector in Albania.

Gërxhani, K. (1998). Politico-economic institutions and the informal sector: a spontaneous free market in Albania. Institution in Transition Conference. Bled, Slovenia.

Gërxhani, K. (2003). Politico-economic institutions and the informal sector in Albania. Amsterdam Institute for Advanced Labour Studies (AIAS) Research Report 03/12.

Gobbi, G., \& Zizza, R. (2007, November). Does the underground economy hold back financial deepening? Evidence from the Italian credit market. Bank of Italy, pp. 1-42.

Guttman, P. M. (1977). The subterranean economy. Financial Analysts Journal, 34:1, pp. 24 - 27.

Kaufmann, D., \& Kaliberda, A. (1996). Integrating the unofficial economy into the dynamics of post socialist economies: a framework of analysis and evidence. World Bank Policy Research WP 1691.

Loayaza, N. V. (1997). The economics of the informal sector: a simple model and some empirical evidence from Latin America. Washington, DC: The World Bank.

Meksi, E. (2012). Uncertainity of the quality of early estimates of GDP. IC in Information Systems and Technological Innovations: their application in the economy. Tirana, Albania: University of Tirana.

Mlinga, R. S., \& Wells, J. (2002). Collaboration between informal and formal enterprises in the construction sector in Tanzania. Habitat International Vol. $26,269-280$.

Muço, M., \& Sanfey, P. (2002). SME development policy in Albania: developing support institutions in an unstable enviroment. In W. Barlett, M. Bateman, \& M. Vehovec, Small Enterprise Development in South East Europe: Policies for Sustainable Growth (pp. 229-239). Kluwer Academic Press.

Muço, M., Peter, S., Luçi, E., \& Hashorva, G. (2004). Private sector and labour market developments in Albania: formal versus informal. The wiiw Balkan Observatory, 1-48.

OECD. (2004). The informal economy in Albania. Analysis and policy recommendations. Central European Initiative (CEI).

Öğünç, F., \& Yilmaz, G. (2000, September). Estimationg the underground economy in Turkey. The central bank of the Republic of Turkey.

Olters, J. P. (2003). Albania's informal economy: an impediment to economic development? International Monetary Fund avaiable at: www.bankofalbania.org/web/pub/JanPeterOlters_240_1.pdf on 18 February 2010. 
Ruli, G. (2003). Characteristics of the informal sector development in Albnia. In B. Belev, The informal economy in the EU accession countries: size, shape, scope, trends and challenges. (pp. 239-247). Gütersloh, Germany: Bertelsmann Verlag.

Schneider, F. (2002). The value added of underground activities: size and measurement of the shadow economies of 110 countries all over the world. University of Linz, Austria.

Schneider, F., Buehn, A., \& Montenegro, C. E. (2010). New estimates for the shadow economies all over the World. International Economic Journal, Vol. 24, No. 4, 443-461.

UNDP. (1995). Albanian human development report. United Nations Development Program.

World Bank. (2006). Status of land reform and real property markets in Albania. The World Bank Officie, Tirana. 